\title{
FAKTOR-FAKTOR YANG BERHUBUNGAN DENGAN PERILAKU SAFETY DRIVING PADA SUPIR TRAVEL DI PT. LIBRA WISATA TRANSPORT
}

\author{
Ade Dita Puteri ${ }^{1}$,Azimah Mardyatun Nisa ${ }^{2}$ \\ Program Studi S1 Kesehatan Masyarakat \\ Universitas Pahlawan Tuanku Tambusai \\ Adedita10@gmail.com
}

\begin{abstract}
Safety Driving is the basis for further driving training that pays attention to the safety of drivers and passengers. Safety Driving is influenced by human factors such as age, education, length of work, knowledge, vehicle factors such as passenger load capacity, environmental factors in this condition of road and weather. The purpose of this study is to know the factors relating to correlation safety driving of travel driver at PT. Libra Wisata Transport Pekanbaru year 2019. This research is a quantitative study of analytics with a cross-sectional approach. This research was conducted on June 20-25, 2019 with the population in this research is the travel driver of PT. Libra Wisata Transport Pekanbaru, which was 40 people using the Total Sampling technique. independent variables are age, employment, education, length of work, knowledge, and driving completeness, while the dependent variables are the behavior of Safety Driving. The instruments used in data collection are questionnaires. Data analysis is conducted with the analysis of univariate and bivariate with Chi-Square test. The results of the research can be a relationship between age, employment, education, duration of work, knowledge and completeness of driving with the behavior of Safety Driving. It is suggested to the travel to be able to conduct training on Safety Driving to the all of driver, and conduct evaluation on the implementation of Safety Driving training, so that the results of the training can make the driver Act securely In driving. In addition, the driver is expected to always obey the ordinances of the traffic provisions.
\end{abstract}

Keywords : behavior of Safety Driving, travel driver

\begin{abstract}
ABSTRAK
Safety Driving merupakan dasar pelatihan mengemudi yang lebih lanjut yang lebih memperhatikan keselamatan bagi pengemudi dan penumpang. Safety Driving dipengaruhi faktor manusia seperti umur, pendidikan, lama bekerja, pengetahuan, faktor kendaraan seperti kapasitas muatan penumpang, faktor lingkungan dalam hal ini kondisi jalan serta cuaca. Tujuan penelitian ini adalah untuk mengetahui faktor-faktor yang berhubungan dengan perilaku safety driving pada sopir Travel Di PT. Libra Wisata Transport Pekanbaru Tahun 2019. Penelitian ini merupakan penelitian kuantitatif analitik dengan pendekatan cross sectional. Penelitian ini dilakukan pada tanggal 20-25 Juni Tahun 2019 dengan populasi dalam penelitian ini adalah Sopir Travel PT. Libra Wisata Transport Pekanbaru yang berjumlah 40 orang menggunakan teknik Total Sampling. Variabel bebas adalah umur, masa kerja, pendidikan, lama kerja, pengetahuan, kondisi jalan, kondisi cuaca dan kelengkapan berkendara, sedangkan variabel terikat adalah perilaku Safety Driving. Instrumen yang
\end{abstract}


digunakan dalam pengumpulan data adalah kuesioner. Analisis data dilakukan dengan analisis univariat dan bivariat dengan uji Chi-Square. Hasil penelitian di dapat ada hubungan antara umur, masa kerja, pendidikan, lama kerja, pengetahuan dan kelengkapan berkendara dengan perilaku Safety Driving. Disaran bagi pihak travel untuk dapat mengadakan pelatihan mengenai Safety Driving kepada seluruh sopir, dan melaksanakan evaluasi terhadap penyelenggaraan pelatihan Safety Driving, agar hasil dari pelatihan tersebut dapat menjadikan sopir bertindak aman dalam berkendara. Selain itu, sopir diharapkan untuk selalu mematuhi tata cara ketentuan berlalu lintas.

\section{Kata Kunci $\quad$ : Perilaku Safety Driving, Sopir Travel}

\section{PENDAHULUAN}

Cidera dan kematian akibat kecelakaan lalu lintas merupakan masalah besar dan telah menjadi masalah kesehatan masyarakat yang penting di seluruh dunia (Departement Perhubungan Republik Indonesia, 2009). Menurut World Health Organization (WHO, 2018), pertahun sekitar 1,35 juta orang meninggal akibat kecelakaan lalu lintas, jumlah tersebut berarti tiap 24 detik ada nyawa yang melayang akibat kecelakaan lalu lintas. WHO memperkirakan akan terdapat jumlah korban yang meningkat menjadi 1,9 juta orang pada tahun 2020.

Jumlah kecelakaan di Indonesia menurut data the global report on road safety tahun 2015 yang dikeluarkan WHO, Indonesia menempati posisi ke tiga sebagai negara dengan jumlah kecelakan lalu lintas di Asia setelah Tiongkok dan India dengan total 38.279 kematian akibat kecelakaan lalu lintas dengan jumlah korban meninggal sekitar 0,015 persen dari total populasi penduduk Indonesia. Data WHO tahun 2011 menyebutkan bahwa sebanyak 67\% korban kecelakaan lalu lintas berada pada usia produktif, yakni 22-50 tahun. Menurut data Badan Pusat Statistik (BPS) Indonesia pada tahun 2017 jumlah kecelakaan lalu lintas sebesar 103.228 jiwa dengan jumlah korban meninggal 30.568 orang, luka berat 14.395 orang, dan luka ringan 119.945 orang. Berdasarkan jenis kendaraan yang mengalami kecelakaan adalah sepeda motor sebesar 52,5\%, mobil pribadi 20\%, truk17,5\% dan angkutan umum $10 \%$ (Korlantas Polri, 2015).

Departemen Perhubungan Republik Indonesia mengumumkan sekitar $85 \%$ kejadian kecelakaan disebabkan oleh faktor pengendara. Faktor-faktor tersebut antara lain pengemudi tidak sabar dan tidak mau mengalah (52\%), menyalip atau mendahului (17\%), berkecepatan tinggi (11\%), sedangkan penyebab lainnya seperti pelanggaran rambu, kondisi pengemudi dan lain-lain berkisar antara 0,5 sampai 5\% (Muhaz, 2013).

Safety Driving merupakan dasar pelatihan mengemudi yang lebih lanjut yang lebih memperhatikan keselamatan bagi pengemudi dan penumpang. Safety Driving di rancang untuk meningkatkan kesadaran pengemudi terhadap segala kemungkinan yang terjadi selama mengemudi (Indonesia Defensive Driving Center, 2009). Safety Driving dipengaruhi oleh beberapa faktor antara lain faktor manusia seperti umur, pendidikan, lama bekerja, pengetahuan, faktor kendaraan seperti kapasitas muatan penumpang, faktor lingkungan dalam hal ini kondisi jalan serta cuaca (Bustan, 2007).

Hasil Penelitian Varmazya (2013), di Tahenran Iran diketahui terdapat hubungan negatif antara umur dengan kejadian 
kecelakaan pada sopir angkutan umum. Semakin tua usia sopir bukan semakin rendah kejadian kecelakaan. Faktor perilaku sopir dalam Safety Driving, jam kerja perminggu, serta kondisi bus berhubungan secara positif dengan kejadian kecelakaan. Semakin baik perilaku sopir dalam Safety Driving, semakin mengurangi resiko kecelakaan. Penelitian Rifal, dkk (2015) menjelaskan faktor pendidikan sopir, tingkat pengetahuan, masa kerja, perilaku mengemudi menjadi faktor yang berhubungan dengan kecelakaan lalu lintas pada supir Bus PO. Jember Indah. Penelitian Avendika, dkk (2016) dengan judul faktor-faktor yang berhubungan dengan Safety Driving pada pengemudi bus, menjelaskan bahwa terdapat hubungan yang signifikan antara masa kerja, sikap, pelatihan Safety Driving, peraturan, kondisi kendaraan peran teman sebaya, dan pengetahuan sopir dengan perilaku Safety Driving.

Berdasarkan hasil survey awal yang dilakukan di PT. Libra Wisata Transport Pekanbaru, bahwa ada sopir yang bekerja lebih dari 8 jam perhari, perilaku sopir selama mengemudikan mobil pernah mengemudikan dengan kecepatan tinggi, dan tidak memakai sabuk pengaman (safety belt), pengemudi juga terkadang mengambil jalur sebelah kiri pada saat menyalip kendaraan lain, atau menerobos lampu merah jika memungkinkan, merokok, dan menerima telpon pada saat mengendarai mobil. Berdasarkan masalah tersebut, maka peneliti tertarik untuk meneliti "Faktor-Faktor Yang Berhubungan Dengan Perilaku Safety Driving Pada Sopir Angkutan Umum Travel Di PT. Libra Wisata Transport Pekanbaru Tahun 2019”.

Tujuan dari penelitian ini adalah Untuk mengetahui Faktor-Faktor Yang
Berhubungan Dengan Perilaku Safety Driving Pada Sopir Travel Di PT. Libra Wisata Transport Pekanbaru.

\section{METODE}

Jenis penelitian yang digunakan adalah penelitian kuantitatif analitik dengan pendekatan Cross sectional. Penelitian ini dilakukan pada tanggal 20-25 Juni 2019. Tempat Penelitian di PT. Libra Wisata Transport Pekanbaru. Populasi dalam penelitian ini adalah Sopir Travel PT. Libra Wisata Transport Pekanbaru yang berjumlah 40 orang dengan teknik pengambilan sampel adalah Total sampling yaitu teknik pengambilan sampel dimana jumlah sampel sama dengan populasi.

\section{HASIL}

\section{Analisis Univariat \\ Umur}

Tabel 4.1 Distribusi Frekuensi Karakteristik Responden Berdasarkan Umur Sopir Travel di PT. Libra Wisata Transport Pekanbaru Tahun 2019

\begin{tabular}{|c|c|c|c|} 
No & Umur (Tahun) & Jumlah & Persentase (\%) \\
\hline 1 & $<30$ & 21 & 52,50 \\
\hline 2 & 230 & 19 & 47,50 \\
\hline \multicolumn{2}{|c|}{ Total } & 40 & 100 \\
\hline
\end{tabular}

Sumber: Penyebaran Kuesioner

Berdasarkan tabel 4.1 dapat diketahui bahwa sebanyak 21 responden $(52,50 \%)$ memiliki umur $<30$ tahun, dan sebanyak 19 responden $(47,50 \%)$ memiliki umur $\geq 30$ tahun.

\section{Masa Kerja}

Tabel 4.2 Distribusi Frekuensi Karakteristik Responden Berdasarkan Masa Kerja Sopir Travel di PT. Libra Wisata Transport Pekanbaru Tahun 2019

\begin{tabular}{c|c|c|c|}
\hline No & Masa Kerja (Tahun) & Jumlah & Persentase (\%) \\
\hline 1 & $<5$ & 20 & 50,00 \\
\hline 2 & $\geq 5$ & 20 & 50,00 \\
\hline \multicolumn{2}{|c|}{ Total } & 40 & 100 \\
\hline
\end{tabular}

Sumber: Penyebaran Kuesioner 
Berdasarkan tabel 4.2 dapat diketahui bahwa sebanyak 20 responden $(50,00 \%)$ memiliki masa kerja $<5$ tahun, dan sebanyak 20 responden $(50,00 \%)$ memiliki masa kerja $\geq 5$ tahun.

\section{Pendidikan}

Tabel 4.3 Distribusi Frekuensi Karakteristik Responden Berdasarkan Tingkat Pendidikan Sopir Travel di PT. Libra Wisata Transport Pekanbaru Tahun 2019

\begin{tabular}{|c|c|c|c|}
\hline No & Pendidikan & Jumlah & Persentase (\%) \\
\hline 1 & Pendidikan Rendah (SD dan SMP) & 19 & 47,50 \\
\hline 2 & $\begin{array}{c}\text { Pendidikan Tinggi (SMU/SMK, } \\
\text { Akademik/Perguruan Tinggi) }\end{array}$ & 21 & 52,50 \\
\hline \multicolumn{2}{|c|}{ Total } & 40 & 100 \\
\hline
\end{tabular}

Sumber: Penyebaran Kuesioner

Berdasarkan tabel 4.3 dapat diketahui bahwa sebanyak 19 responden $(47,50 \%)$ memiliki tingkat pendidikan rendah, dan sebanyak 21 responden $(52,50 \%)$ memiliki tingkat pendidikan tinggi.

\section{Lama Kerja}

Tabel $4.4 \quad$ Distribusi $\quad$ Frekuensi Karakteristik Responden Berdasarkan Lama Kerja Sopir Travel di PT. Libra Wisata Transport Pekanbaru Tahun 2019

\begin{tabular}{|c|c|c|c|}
\hline No & Lama Kerja (Jam) & Jumlah & Persentase (\%) \\
\hline 1 & Buruk $>8)$ & 24 & 60,00 \\
\hline 2 & Baik $(\leq 8)$ & 16 & 40,00 \\
\hline \multicolumn{2}{|c|}{ Total } & 40 & 100 \\
\hline
\end{tabular}

Sumber: Penyebaran Kuesioner

Berdasarkan tabel 4.4 dapat diketahui bahwa sebanyak 24 responden $(60,00 \%)$ memiliki lama kerja >8 jam, dan sebanyak 16 responden $(40,00 \%)$ memiliki lama kerja $\leq 8$ jam.

\section{Pengetahuan}

Tabel 4.5 Distribusi Frekuensi Responden Berdasarkan Tingkat Pengetahuan Sopir Travel di PT. Libra Wisata Transport Pekanbaru Tahun 2019

\begin{tabular}{|c|c|c|c|}
\hline No & Pengetahuan & Jumlah & Persentase(\%) \\
\hline 1 & Rendah & 13 & 32,50 \\
\hline 2 & Tinggi & 27 & 67,50 \\
\hline \multicolumn{2}{|c|}{ Total } & 40 & 100 \\
\hline
\end{tabular}

Sumber: Penyebaran Kuesioner

Berdasarkan tabel 4.5 dapat diketahui bahwa sebanyak 13 responden $(32,50 \%)$ memiliki pengetahuan rendah, dan sebanyak 27 responden $(67,50 \%)$ memiliki pengetahuan tinggi.

\section{Kelengkapan Berkendara}

Tabel 4.6 Distribusi Frekuensi Responden Berdasarkan Kelengkapan Berkendara Sopir Travel di PT. Libra Wisata Transport Pekanbaru Tahun 2019

\begin{tabular}{|c|c|c|c|}
\hline No & Kelengkapan Berkendara & Jumlah & Persentase (\%) \\
\hline 1 & Tidak lengkap & 16 & 40,00 \\
\hline 2 & Lengkap & 24 & 60,00 \\
\hline \multicolumn{2}{|c|}{ Total } & 40 & 100 \\
\hline
\end{tabular}

Sumber : Penyebaran Kuesioner

Berdasarkan tabel 4.6 dapat diketahui bahwa sebanyak 16 responden $(40,00 \%)$ memiliki kelengkapan berkendara yang tidak lengkap, dan sebanyak 24 responden $(60,00 \%)$ memiliki kelengkapan berkendara yang lengkap.

\section{Perilaku Safety Driving}

Tabel 4.7 Distribusi Frekuensi Responden Berdasarkan Perilaku Safety Driving Sopir Travel di PT. Libra Wisata Transport Pekanbaru Tahun 2019

\begin{tabular}{|c|c|c|c|}
\hline No & $\begin{array}{c}\text { Perilaku Safety } \\
\text { driving }\end{array}$ & Jumlah & $\begin{array}{c}\text { Persentase } \\
(\%)\end{array}$ \\
\hline 1 & Tidak Aman & 21 & 52,50 \\
\hline 2 & Aman & 19 & 47,50 \\
\hline \multicolumn{2}{|c|}{ Total } & 40 & 100 \\
\hline
\end{tabular}

Sumber: Penyebaran Kuesioner

Berdasarkan tabel 4.7 dapat diketahui bahwa sebanyak 21 responden $(52,50 \%)$ memiliki perilaku Safety driving yang tidak aman, dan sebanyak 19 responden $(47,50 \%)$ memiliki perilaku Safety driving yang aman. 


\section{Analisis Bivariat}

Hubungan Umur dengan Perilaku Safety

Driving

Tabel 4.8 Hasil Uji Chi-Square Hubungan antara Umur dengan Perilaku Safety Driving Sopir Travel di PT. Libra Wisata Transport Pekanbaru Tahun 2019

\begin{tabular}{|c|c|c|c|c|c|c|c|}
\hline \multirow{3}{*}{ Umur(Tahun) } & \multicolumn{4}{|c|}{ Perilaku Safety Driving } & \multirow{2}{*}{\multicolumn{2}{|c|}{ Jumlah }} & \multirow{3}{*}{ p value } \\
\hline & \multicolumn{2}{|c|}{ Tidak Aman } & \multicolumn{2}{|c|}{ Aman } & & & \\
\hline & $\mathrm{N}$ & $\%$ & $\mathrm{~N}$ & $\%$ & $\mathrm{~N}$ & $\%$ & \\
\hline$<30$ & 16 & 76,19 & 5 & 23,81 & 21 & 100 & \multirow{3}{*}{0,002} \\
\hline$\geq 30$ & 5 & 26,32 & 14 & 73,68 & 19 & 100 & \\
\hline Total & 21 & 52,50 & 19 & 47,50 & 40 & 100 & \\
\hline
\end{tabular}

Sumber: Data Olahan, 2019

Dari hasil uji Chi square nilai signifikansi ( $p$-value) kedua variabel tersebut sebesar 0,002, karena nilai signifikansi tersebut di bawah 0,05, ini berarti ada hubungan antara umur terhadap perilaku safety driving. Menurut Notoadmodjo (2012), perilaku bergantung pada karakteristik atau faktor lain dari tenaga kerja itu sendiri. Salah satunya karakteristik dari tenaga kerja adalah faktor umur yang mempengaruhi perilaku.

Umur dapat mempengaruhi seseorang dalam berperilaku berkendara yang aman, pekerja yang berumur $\geq 30$ tahun (tua) lebih matang dan lebih terampil dalam berperilaku daripada pekerja yang berumur < 30 tahun (muda). Pekerja yang berumur $\geq 30$ tahun diharapkan dapat menunjukkan perilaku yang lebih baik karena cenderung lebih berpengalaman dalam menghadapi situasi kerja dibandingkan dengan pekerja yang $<30$ tahun (Suma'mur, 1998). Hasil penelitian Rukhfiati (2010) menjelaskan bahwa pengendara yang berumur di atas 30 tahun lebih matang dan lebih pengalaman dalam berperilaku mengendarai sepeda motor, daripada pengendara yang berumur di bawah 30 tahun. Hal tersebut dikarenakan umur merupakan salah satu faktor yang berhubungan dengan perilaku seseorang. Seseorang yang memiliki umur yang matang akan berperilaku aman dalam berkendara.

\section{Hubungan Masa Kerja dengan Perilaku Safety Driving}

Tabel 4.9 Hasil Uji Chi-Square Hubungan antara Masa Kerja dengan Perilaku Safety Driving Sopir Travel di PT. Libra Wisata Transport Pekanbaru Tahun 2019

\begin{tabular}{|c|c|c|c|c|c|c|c|}
\hline \multirow{3}{*}{$\begin{array}{c}\text { Mass Kerja } \\
\text { (Thhom) }\end{array}$} & \multicolumn{4}{|c|}{ Perllaku Safery Driving } & \multirow{2}{*}{\multicolumn{2}{|c|}{ Jumlah }} & \multirow{3}{*}{ pvalue } \\
\hline & \multicolumn{2}{|c|}{ Tidak Aman } & \multicolumn{2}{|c|}{ Aman } & & & \\
\hline & $n$ & $\%$ & $n$ & $\%$ & N & $\%$ & \\
\hline$<5$ & 14 & 70,00 & 6 & 30,00 & 20 & 100 & \\
\hline 25 & 7 & 35,00 & 13 & 65,00 & 20 & 100 & 0,027 \\
\hline Total & 21 & 52,50 & 19 & 47,50 & 40 & 100 & \\
\hline
\end{tabular}

Sumber: Data Olahan, 2019

Dari hasil uji Chi square nilai signifikansi (p-value) kedua variabel tersebut sebesar 0,027 , karena nilai signifikansi tersebut di bawah 0,05 , ini berarti ada hubungan antara masa terhadap perilaku safety driving.

Masa kerja berkendara mempunyai hubungan dengan perilaku safety driving karena sopir yang memiliki masa kerja yang lebih lama cenderung lebih berpengalaman dan terampil dibandingkan dengan sopir dengan masa kerja yang lebih sedikit. Karena semakin lama masa kerja sopir semakin disiplin dalam keamanan berkendara, karena tingkat pengetahuan sopir tentang perilaku safety driving lebih tinggi. Sopir yang mempunyai masa kerja yang lama, cenderung waspada terhadap bahaya kecelakaan lalu lintas sehingga sopir membiasakan diri untuk berperilaku aman dalam berkendara (suma'mur).

Hasil ini sesuai dengan penelitian yang dilakukan Avendika (2016), dengan judul faktor-faktor yang berhubungan dengan safety driving pada pengemudi bus di terminal Terboyo Semarang. Dengan 
kesimpulan bahwa mengemudi merupakan pekerjaan yang bersifat khusus yang menuntut keterampilan, kewaspadaan, serta konsentrasi seseorang dalam mengemudikan kendaraan pada kondisi apapun. Dengan pengalaman mengemudi menjadikan seseorang memiliki pengetahuan dan pengalaman mengenai bagaimana semestinya mengemudi.

\section{Hubungan Pendidikan Dengan Perilaku Safety Driving}

Tabel 4.10 Hasil Uji Chi-Square Hubungan antara Pendidikan dengan Perilaku Safety Driving Sopir Travel di PT. Libra Wisata Transport Pekanbaru Tahun 2019

\begin{tabular}{c|c|c|c|c|c|c|c}
\hline \multirow{2}{*}{ Pendidikan } & \multicolumn{4}{|c|}{ Perilaku Safety Driving } & \multicolumn{2}{|c|}{ Jumlah } & \multirow{3}{*}{ p value } \\
\cline { 2 - 7 } & \multicolumn{2}{|c|}{ Tidak Aman } & \multicolumn{2}{|c|}{ Aman } & \multicolumn{2}{|c}{} & \\
\cline { 2 - 7 } & $\mathrm{n}$ & $\%$ & $\mathrm{n}$ & $\%$ & $\mathrm{~N}$ & $\%$ & \\
\hline Pendidikan Rendah (SD dan SMP) & 14 & 73,68 & 5 & 26,32 & 19 & 100 & \\
\hline $\begin{array}{c}\text { Pendidikan Tinggi (SMU/SMK, } \\
\text { AkademikPerguruan Tinggi) }\end{array}$ & 7 & 33,33 & 14 & 66,67 & 21 & 100 & \multirow{2}{*}{0,011} \\
\hline Total & 21 & 52,50 & 19 & 47,50 & 40 & 100 & \\
\hline
\end{tabular}

Sumber: Data Olahan, 2019

Dari hasil uji Chi square nilai signifikansi ( $p$-value) kedua variabel tersebut sebesar 0,011, karena nilai signifikansi tersebut di bawah 0,05, ini berarti ada hubungan antara pendidikan terhadap perilaku safety driving.

Pendidikan merupakan salah satu faktor yang akan mempengaruhi perilaku (Notoadmodjo, 2012). Semakin tinggi tingkat pendidikan seseorang maka semakin baik pula pola pikirnya dalam mencerna informasi-informasi yang dapat mendasari pola perilaku orang tersebut.

Perilaku safety driving merupakan suatu perilaku berkendara dengan aman dimana dalam berperilaku tersebut dibutuhkan pengetahuan terutama tentang safety driving tersebut sedangkan pengetahuan didasari dengan pola pikir yang baik.

Hasil ini sejalan dengan penelitian yang dilakukan oleh Andi Firmansyah dkk (2013) yang berjudul faktor yang berhubungan dengan perilaku safety driving pada pengemudi pengangkut semen curah di PT. Prima Karya Manunggal (PKM) Kab. Pangkep. Menyatakan bahwa lebih tingginya tingkat pendidikan seseorang akan berpengaruh pada perilaku sesorang dalam bertindak untuk lebih baik dan lebih bijak.

\section{Hubungan Lama Kerja Dengan Perilaku Safety Driving}

Tabel 4.11 Hasil Uji Chi-Square Hubungan antara Lama Kerja dengan Perilaku Safety Driving Sopir Travel di PT. Libra Wisata Transport Pekanbaru Tahun 2019

\begin{tabular}{|c|c|c|c|c|c|c|c|}
\hline \multirow{3}{*}{ Lama Kerja (Jam Harn) } & \multicolumn{4}{|c|}{ Perilaku Safety Driving } & \multirow{2}{*}{\multicolumn{2}{|c|}{ Jumlah }} & \multirow{3}{*}{ pvalue } \\
\hline & \multicolumn{2}{|c|}{ Tidak Aman } & \multicolumn{2}{|c|}{ Aman } & & & \\
\hline & $\mathrm{N}$ & $\%$ & $\mathrm{~N}$ & $\%$ & $\mathrm{~N}$ & $\%$ & \\
\hline Bunk $(>8)$ & 16 & 66,67 & 8 & 33,33 & 24 & 100 & \\
\hline Baik $(\leq 8)$ & 5 & 31,25 & 11 & 68,75 & 16 & 100 & 0,028 \\
\hline Total & 21 & 52,50 & 19 & 47,50 & 40 & 100 & \\
\hline
\end{tabular}

Sumber: Data Olahan, 2019

Dari hasil uji Chi square nilai signifikansi (p-value) kedua variabel tersebut sebesar 0,028, karena nilai signifikansi tersebut di bawah 0,05, ini berarti ada hubungan antara lama kerja terhadap perilaku safety driving.

Perturan mengenai lama kerja pada sopir menurut Undang-Undang Republik Indonesia nomor 22 Tahun 2009 ayat 2 disebutkan bahwa bagi pengemudi Kendaraan Bermotor Umum paling lama 8 jam sehari. Lama kerja berhubungan dengan perilaku safety driving karena seorang sopir yang bekerja lebih dari 8 jam sehari akan cenderung mengalami kelelahan dan mengurangi konsentrasi dalam berkendara, hal ini berdampak pada perilaku safety driving yang tidak aman.

Lama kerja akan menyebabkan pengemudi mengalami kelelahan dan bisa menyebabkan pengemudi mengantuk (Beaulieu, 2005). Menurut Marsaid (2013) faktor manusia seperti lelah, mengantuk, 
lengah, mabuk, tidak terampil, tidak tertib dan berkecepatan tinggi menyebabkan potensi kecelakaan lalu lintas. Penelitian ini sejalan dengan hasil penelitian Putra (2015) yang menjelaskan pengemudi yang mengalami kelelahan dapat menimbulkan kantuk. Kelelahan yang dialami pengemudi disebabkan karena durasi mengemudi yang tidak sesuai dengan standar untuk setiap harinya atau setiap minggunya yaitu 9 jam perhari atau 48 jam perminggunya.

\section{Hubungan Pengetahuan Dengan Perilaku Safety Driving}

Tabel 4.12 Hasil Uji Chi-Square Hubungan antara pengetahuan dengan Perilaku Safety Driving Sopir Travel di PT. Libra Wisata Transport Pekanbaru Tahun 2019

\begin{tabular}{|c|c|c|c|c|c|c|c|}
\hline \multirow{3}{*}{ Pengetahuan } & \multicolumn{4}{|c|}{ Perilaku Safety Driving } & \multirow{2}{*}{\multicolumn{2}{|c|}{ Jumlah }} & \multirow{3}{*}{ p value } \\
\hline & \multicolumn{2}{|c|}{ Tidak Aman } & \multicolumn{2}{|c|}{ Aman } & & & \\
\hline & n & $\%$ & $n$ & $\%$ & $\mathrm{~N}$ & $\%$ & \\
\hline Rendah & 10 & 76,92 & 3 & 23,08 & 13 & 100 & \\
\hline Tinggi & 11 & 40,74 & 16 & 59,26 & 27 & 100 & 0,032 \\
\hline Total & 21 & 52,50 & 19 & 47,50 & 40 & 100 & \\
\hline
\end{tabular}

Sumber: Data Olahan, 2019

Dari uji uji Chi square nilai signifikansi (p-value) kedua variabel tersebut sebesar 0,032, karena nilai signifikansi tersebut di bawah 0,05, ini berarti ada hubungan antara pengetahuan terhadap perilaku safety driving.

Pengetahuan atau kognitif merupakan domain yang sangat penting untuk terbentuknya tindakan seseorang (overt behavior) (Notoatmodjo, 2012). Green (1980) menyatakan bahwa peningkatan pengetahuan tidak selalu menyebabkan perubahan perilaku, tetapi pengetahuan sangat penting diberikan sebelum individu melakukan suatu tindakan. Tindakan akan sesuai dengan pengetahuan apabila individu menerima isyarat yang cukup kuat untuk memotivasi dirinya untuk bertindak sesuai dengan pengetahuannya.
Menurut Ferry Efendy dan Makhfudli (2009), tindakan atau perilaku yang didasari oleh pengetahuan akan lebih diingat dan langgeng daripada tindakan atau perilaku yang tidak di dasari oleh pengetahuan. Menurut Kunwadee Rojpaisarnkit (2012) pengetahuan berkendara yang kurang, akan menyebabkan persepsi yang salah mengenai keadaan lalu lintas ketika seseorang berkendara. Hal tersebut mengakibatkan pengendara mengambil tindakan yang dapat mengarah kepada kecelakaan lalu lintas.

Berdasarkan penelitian Augustie (2017) yang berjudul faktor-faktor yang berhubungan dengan perilaku safety driving pada sopir bus di terminal tirtonadi, menyatakan bahwa. Sopir yang memiliki pengetahun tinggi cenderung mempunyai perilaku safety driving yang aman, di bandingkan dengan pengetahun rendah. Pengetahuan sopir yang tinggi dapat dipengaruhi oleh faktor pengalaman, faktor lingkungan kerja, faktor latar belakang pendidikan, yang dimana semakin tinggi tingkat pendidikan maka semakin tinggi tingkat pengetahuan seseorang.

\section{Hubungan Kelengkapan Berkendara Dengan Perilaku Safety Driving}

Tabel 4.13 Hasil Uji Chi-Square Hubungan antara kelengkapan berkendara dengan Perilaku Safety Driving Sopir Travel di PT. Libra Wisata Transport Pekanbaru Tahun 2019

\begin{tabular}{|c|c|c|c|c|c|c|c|}
\hline \multirow{3}{*}{ Kelengkapan Berkendara } & \multicolumn{4}{|c|}{ Perllaku Safety Driving } & \multirow{2}{*}{\multicolumn{2}{|c|}{ Jumlah }} & \multirow{3}{*}{ pvalue } \\
\hline & \multicolumn{2}{|c|}{ Tidak Aman } & \multicolumn{2}{|c|}{ Aman } & & & \\
\hline & n & $\%$ & n & $\%$ & N & $\%$ & \\
\hline Tidaklengkap & 12 & 75,00 & 4 & 25,00 & 16 & 100 & \\
\hline Lengkap & 9 & 37,50 & 15 & 62,50 & 24 & 100 & 0,020 \\
\hline Total & 21 & 52,50 & 19 & 47,50 & 40 & 100 & \\
\hline
\end{tabular}

Sumber: Data Olahan, 2019 
Dari hasil uji Chi square nilai signifikansi ( $p$-value) kedua variabel tersebut sebesar 0,020 , karena nilai signifikansi tersebut di bawah 0,05, ini berarti ada hubungan antara kelengkapan terhadap perilaku safety driving.

Kelengkapan berkendara merupakan salah satu faktor pendorong pembentukan perilaku (Lawrence Green, 1980). Kelengkapan berkendara diatur oleh Undang-Undang RI Nomor 22 Tahun 2009 Tentang Lalu Lintas dan Angkutan Jalan (LLAJ). Green (2005), menyatakan bahwa ketersediaan sarana merupakan salah satu faktor pemungkin yang memfasilitasi motivasi untuk dapat diwujudkan menjadi kenyataan, karena faktor predisposisi (pengetahuan, sikap, dll) belum cukup untuk membuat seseorang berperilaku, perlu adanya fasilitas yang mendukung terjadinya perilaku tersebut.

Pada saat berkendara kelengkapan berkendara yang harus dibawa yaitu membawa kelengkapan surat berupa SIM dan STNK, sabuk keselamatan, ban cadangan, segitiga pengaman, dongkrak pembuka, ban, dan kotak P3K. Kelengkapan berkendara merupakan hal yang penting dalam safety driving. Semakin lengkap semua yang dibutuhkan dalam berkendara maka akan semakin aman perilaku safety driving sopir.

\section{Kesimpulan}

Ada hubungan antara umur, masa kerja, pendidikan, lama kerja, pengetahuan, dan kelengkapan berkendara dengan perilaku safety driving pada sopir travel di PT. Libra Wisata Transport Pekanbaru Tahun 2019.

\section{DAFTAR PUSTAKA}

1. Ahmad, A. (2017). "Faktor Yang Mempengaruhi Perilaku Mengemudi Tidak aman Pada Sopir Bus Trayek Jember-Kencong-Lumajang”. Skripsi. Jember : FKM UNIVERSITAS JEMBER.

2. Adinugroho, N., B. Kurniawan., dan I. Wahyuni. (2014). "Faktor Yang Berhubungan Dengan Praktik Mengemudi Tidak Aman Pada Pengemudi Angkutan Kota Jurusan Banyumanik-Johar Kota Semarang". Jurnal kesehatan masyarakat, 2 .

3. Amalia.(2017). "Gambaran Perilaku Keselamatan Berkendara Pada Pelajar SMA Dua Mei Ciputat Timur". Skiripsi. Semarang : UNNES.

4. Annisa, H.(2016). "Analisis Risiko Kecelakaan Lalu Lintas Berdasarkan Pengetahuan, Penggunaan Jalur, Dan Kecepatan Berkendara". Jurnal Berkala Epidemiologi. Volume 4.

5. Anonim, (2011). Nih, Bedanya Safety Driving dan Defensive Driving, http://mobil.otomotifnet.com/read/20 11/12/05/326065/212/28/Nih-

BedanyaSafety-Driving-dan-

Defensive-Driving. Diperoleh tanggal 10 Februari 2019.

6. Anonim, (2012), Apa Beda Safety Driving dengan Defensive Driving?, http://news.detik.com/read/2012/12/1 6/112 804/2119708/727/apa-bedasafety-drivingdengan-defensivedriving?9922022. Diperoleh tanggal 10 Februari 2019.

7. Ariwibowo. (2013). "Hubungan antara Umur, Tingkat Pendidikan, Pengetahuan, Sikap Terhadap Praktik Safety Driving Awareness Pada Pengendara Ojek Sepeda Motor". 
Jurnal Kesehatan Masyarakat. Volume 2.

8. AT\&T, (2015), Top Ten Safe Driving Tips, https://www.att.com/Common/about_ us/txting_driving/td_topten_safe_driv ing. pdf. Diperoleh tanggal 25

Februari 2019.

9. Augustie.(2017). "Faktor-Faktor yang Berhubungan dengan Perilaku Safety Driving pada Sopir Bus Di Terminal Tirtonadi”. Skripsi.Surakarta: FKM UMS.

10. Avendika, B., Bina, K., dan Ida, W. (2016). "Faktor-Faktor Yang Berhubungan Dengan Safety Driving Pada Pengemudi Bus Ekonomi Trayek Semarang-Surabaya Di Terminal Terboyo Semarang”. Jurnal Kesehatan Masyarakat. Volume 4.

11. Azwar, S. (2012). Reliabilitas dan Validitas. Yogyakarta: Pustaka Pelajar.

12.BIN. (2019), Kecelakaan Lalu Lintas Menjadi Pembunuh Terbesar Ketiga, http://www.bin.go.id/. Diperoleh tanggal 10 Februari 2019.

13. Badan Pusat Statistik. (2016) Data Kecelakaan Lalu Lintas.

14.Bugnin, B. (2010). Metodologi Penelitian Kuantitatif : Komunikasi, Ekonomi Dan Kebijakan Publik Serta Ilmu-Ilmu Sosial Lainnya. Jakarta: Kencana.

15.DepHub RI, (2011), Kecelakaan Lalu Lintas Tempati Urutan Tiga Penyebab Kematian. Jakarta: Pusat Komunikasi Publik, http://www.dephub.go.id. Diperoleh tanggal 10 Februari 2019.

16.Dian, P., Baju, W., dan Ekawati. (2015). “Analisis Faktor-Faktor Yang Mempengaruhi

Kebiasaan
Mengemudi Tidak Aman Pada Sopir Angkot Daerah Tembalang Kota Semarang". Jurnal Kesehatan Masyarakat. Volume 3.

17. Firmasyah, A. (2013). "Faktor Yang Berhubungan Dengan Perilaku Safety Driving Pada Pengemudi Mobil Angkutan Semen Curah di PT. Prima Karya Manunggal (PKM) Kab Pangkeptahun 2013”. Skripsi. Makasar:Universitas Hasanudin

18. Gahari, (2005), Berkendara Secara Aman Untuk Hindari Kecelakaan, http://www.driver.com. Diperoleh tanggal 10 Februari 2019.

19. Hadani, (2011), Cuaca Buruk dapat Mengakibatkan Kecelakaan, http://www.kompas.com/kompascetak/0997/30/sorotan/978654.htm. Diperoleh tanggal 25 Februari 2019.

20. Hidayat, A.A.(2010). Metode Penelitian Kesehatan Paradigma Kuantitatif. Jakarta: Heath Books.

21.HSA, (2012), Safe Driving For Works Drivers Handbook, http://www.hsa.ie/eng. Diperoleh tanggal 10 Februari 2019.

22. Humas Polri, (2015), Angka Kecelakaan Lalu Lintas di Indonesia. http://Humas.polri.go.id. Diperoleh tanggal 25 februari 2019.

23. Kalit, H., Ekawati., dan Ida, W. (2017). "Analisis Faktor-Faktor Yang Mempengaruhi Safety Driving Pada Operator Forklift di Area Kerja Warehouse PT. X Jakarta”. Jurnal Kesehatan Masyarakat. Volume 5.

24. Martono, N. (2010). Metode Penelitian Kuantitatif Analisis Isi dan Analisis Data Sekunder Edisi Revisi 2. Jakarta: Rajawali Pers.

25. Manurung, J, (2019), Faktor Yang Berhubungan Dengan Perilaku Safety 
Riding Pengemudi Ojek Online (Gojek) Di Kota Medan Sumatra Utara. $\quad$ http://jurnal.stikessitihajar.ac.id/index.php/jhsp.

Diperoleh tanggal 25 Juni 2019

26. Mubarak, WI. (2007). Promosi Kesehatan. Yogyakarta: Graha Ilmu.

27. Muthia, (2016), Faktor-Faktor yang Berhubungan dengan Praktik Safety Driving Pada Pengemudi Road Tank PT Petamina EP Asset 4 Field Cepu. Semarang : Universitas Diponegoro Semarang. http://ejounals1.undip.ac.id/index.php/jkm.

Diperoleh tanggal 10 Februari 2019.

28. Notoatmodjo, Soekidjo. (2003). Pengantar Pendidikan Kesehatan dan Ilmu Perilaku. Yogyakarta : Andi Offset.

29. Notoatmodjo. (2007). Promosi Kesehatan dan Ilmu Perilaku.Jakarta: Rineka Cipta.

30. Nurcahyo, A. (2014), Faktor Yang Berhubungan Dengan Praktik Safety Driving Pada Pengemudi Angkutan Kota Jurusan Banyumanik-Johar Kota Semarang. Semarang: Universitas Diponegoro Semarang. http://ejournals1.undip.ac.id/index.php/jkm.

Diperoleh tanggal 10 februari 2019.

31. Oktarina, Sheila. (2012). "Faktorfaktor yang Berhubungan dengan Safety Driving pada Pengemudi Mobil Tangki Terminal BBM Medan Group PT Pertamina (Persero) Labuhan Deli Medan Tahun 2011". Skripsi. Medan: Fakultas Kesehatan Masyarakat Universitas Sumatera Utara.

32. Pello, Darmawan Ade.(2015), DasarDasar Transportasi Udara. http://ppsdma.bpsdm.dephub.go.id/w
eb/wpcontent/uploads/2015/07/DAS ARDASARTRANSPORTASIUDAR A.docx. Diperoleh tanggal 10 Februari 2019.

33. Pradipta, E. G., Suroso, S., \& Suharini, E. (2014). Efektivitas BRT (Bus Rapid Transit) Trans Semarang sebagai Moda Transportasi di Kota Semarang. Geo-Image, 3(2).

34. Rifa'i, N. (2017). "Hubungan Antara Self Control Dengan Safety Driving Pada Pengemudi Bus AKAP (Antar Kota Antar Provinsi) Di Kota Solo". Skripsi. Surakarta: universitas Muhammadiyah Surakarta

35. Rizky, Y. (2009), Faktor-faktor yang berhubungan dengan Perilaku Aman (Safety Driving) pada Pengemudi Taxi PT X Tahun 2009. Depok: Fakuktas Kesehatan Masyarakat Universitas Indonesia. http://www.digilib.ui.ac.id. Diperoleh tanggal 10 Februari 2019.

36. Sastroasmoro. (2014). Dasar-dasar Metodoligi Peneitian Klinis (Edisi:5). Jakarta:Sagung Seto.

37. Septiani, N. (2017). "Beberapa Faktor Yang Berhubungan Dengan Perilaku Pekerja Dalam Penerapan Safe Behavior Di PT. Hanil Jaya Steel". The Indonesian Journal Of Occupational Safety Ang Health. Volume 6.

38. Tirtarahardja, U, Sulo, SLL. (2005). Pengantar Pendidikan. Jakarta: Rineka Cipta.

39. Undang-undang No. 22 Tahun 2009 Tentang Lalu Lintas dan Angkutan Umum.

40. Widhiarso, W. (2010). Membuat Kategori Skor Hasil Pengukuran dari Skala. Yogyakarta: Fakultas Psikologi Universitas Gadjah Mada. 